\title{
EVALUATION OF SPATIAL DIFFERENTIATION OF SOCIO-ECONOMIC DEVELOPMENT OF RURAL AREAS IN MAZOWIECKIE PROVINCE IN YEARS 2004-2016
}

\begin{abstract}
Mariola CHRZANOWSKA, Faculty of Applied Informatics and Mathematics, Warsaw University of Life Sciences - SGGW, Nowoursynowska St 166, 02-787 Warsaw, Poland, e-mail: mariola_chrzanowska@sggw.pl (corresponding author)

Monika ZIELIŃSKA-SITKIEWICZ, Faculty of Applied Informatics and Mathematics, Warsaw University of Life Sciences - SGGW, Nowoursynowska St. 166,02-787 Warsaw, Poland, e-mail: monika_zielinska_sitkiewicz@sggw.pl

Mazowieckie Province is a unique area of Poland. It is characterised by social and economic diversification. Located in this province, Warsaw strongly influences the development of neighbouring rural areas. On the other hand, rural municipalities whose socio-economic parameters are among the lowest in the country are located within several dozen kilometres from the centre of the capital. Such disparities show that Mazowieckie is characterised by large interregional differences in its internal structure. This is an interesting research area that requires the analysis of socio-economic development in this region to be conducted in a multidimensional way.

The aim of this study is to evaluate the spatial differentiation of the level of socio-economic development of rural areas in Mazowieckie Province. Linear ordering was used to determine the level of socio-economic development.

The results of the study are consistent with core-periphery theory. The large urban centres that function as the centres for the surrounding rural areas have the greatest impact on the level of rural development. The impact of smaller towns can also be noticed. They often are the local development centres for surrounding villages.
\end{abstract}

Keywords: socio-economic development, rural areas, synthetic measure, Masovian voivodeship

\section{INTRODUCTION}

The accession of Poland to the EU has created a new economic and social quality for rural areas. The support instruments in agriculture used by Poland so far have been adapted to the principles of functioning within a uniform market and to the rules concerning the state aid. One of the key changes was the introduction of instruments of common agricultural policy, commercial and industrial policy. The accession treaty defines the conditions for implementing the common agricultural policy (CAP) for Poland, including significant financial support for rural development. ${ }^{1}$

In Poland, rural areas are defined in an administrative way. These are areas located outside the city limits. However, Brodziński (Brodzinski, 2011) emphasises that the determination of boundaries and delimitation of rural areas is difficult due to the large disproportions in the size of the towns and their layout in the area. These disparities make it impossible to adopt one strategy for rural development. As a consequence, the study of socio-economic development is a subject to a number of studies and analyses (see Bański, Czaplewski, 2008; Chrzanowska, Drejerska, 2016; Pomianek at al, 2013; Stanny, 2015; Wojewódzka-Wiewiórska, Dudek, 2016; Wysocki, 2010; Ziemiańczyk, 2010).

Rural areas are characterised by its special aspect. As shown by numerous literature studies (Stanny, 2015), the processes of socio-economic development do not take place uniformly. The varied nature of space is determined by the level and structure of the development, which also vary in time. Therefore, the dynamics of development processes, particularly in rural areas, are conditioned by two main categories: space and time.

Economic development is a long-term and complex economic and social process involving both quantitative changes, as well as qualitative and structural transformations. This concept takes account of all changes concerning the growth of production, income, employment, all components affecting the economic growth, and what is more, changes in the structure of economy, organization of the society, economic relations and methods of producing goods and services. The increase in the standard of living of the society, the growth of production and public security are some of the many benefits of economic development.

Social development is a complementary component of economic development. This is a multi-stage process of socialchange. It goes in the direction of satisfying the needs. It is a process causing changes, among others: of the structure of society,

\footnotetext{
${ }^{1}$ The share of the II pillar in the Polish CAP for the years of 2007-2013 amounts almost to 40\% (while in the EU it amounts to 23\%, on average).
}

Copyright $(\mathcal{C} 2017$ The Authors. Published by Aleksandras Stulginskis University. This is an open-access article distributed under the terms of the Creative Commons Attribution License (CC-BY 4.0), which permits unrestricted use, distribution, and reproduction in any medium, provided the original author and source are credited. 
its preferences, patterns of behaviour and attitudes of co-existence, systems of social relations, possibilities of comprehensive development. The systematic improvement of the living conditions of the population is the consequence of social development (Sztompka, 2005; Secomski, 1972). Economic development is complementary to social development. This interdependence has been repeatedly described in the literature (Baran at al, 1987; Zając, 2006; Stanny, 2010).

The concept of socio-economic development is a category that covers both the economic development and social development. It is the broadest concept that generally covers the developmental trend of the given country, region or territorial unit. In the context of rural areas, this concept represents the quantitative and qualitative process of changes both in the economy and the community. These are both spatial and time changes in the economic potential, the creation of suitable conditions (opportunities) for earning in the countryside and on the local labour market (suitable conditions, i.e. adequate to modern civilization progress, consistent with advantages of the area, but above all in line with expectations, needs and opportunities of rural residents). The aim of the socio-economic development of rural areas is the creation of such economic and social structures in the local environment that ensure a satisfactory income for the residents and will not lead to unfavourable phenomena (e.g., agrarian overcrowding, depopulation, unemployment, poverty) (Stanny, 2015). As a consequence, the assessment of the development should be considered in a multidimensional aspect, taking into account the diversity of this phenomenon.

The main objective of the study is to determine socio-economic level of rural and rural-urban communes of the Masovian voivodeship in 2004 and 2016 using the method of a multidimensional comparative analysis (synthetic measure taking into account the zero unitarization method).

\section{REASERCH METHODS}

Multidimensional Comparative Analysis (MCA) comprises a group of statistical methods used to study objects (phenomena) described by many features. (Balicki, 2009). Using MCA we can examine complex phenomena, i.e. phenomena which are described by two or more variables. The economic research such as MCA is understood as a collection of various methods designed to detect statistical patterns in collectivities. Multidimensional comparative analysis (MCA) is a comparison of objects defined by many diverse features. The methods used to conduct such an analysis include taxonomic methods, based on comparisons made with application of a distance matrix. (Pluta, 1977). Using MCA, we can solve two categories of problems: study the similarities of objects in terms of complex phenomena, using the methods of classification, and rank objects in terms of a complex phenomenon with the use of linear ordering methods (Stanimir, 2006).

The methods of linear ordering of objects are an important group of MCA methods. They involve the projection of objects from a multidimensional area of features to a straight line. Their goal is to rank the objects from the best to the worst one.(Mynarski, 1992).

However, the methods of linear ordering have some limitations. They are not resistant to untypical observations. The values of the analyzed features are not comparable with analogous features of other objects that are studied.. In such a situation, the objectivity of the synthetic measure being created decreases due to the strong influence of unrepresentative objects on the pattern. Results of ranking also depend on the form of normalisation variables (Zielińska-Sitkiewicz, 2017).

The synthetic measure proposed by K. Kukuła is one of linear ordering methods. (Kukuła, 2012). In the first stage of the procedure each of $\mathrm{k}$ variables is normalised by zero unitarization method proposed also by Kukuła (Kukuła, 2014). Depending on the variable: stimulant $(S)$ or destimulant $(D)$ normalised formula is described by the following formulas (1) and (2):

$$
\begin{gathered}
z_{i j}=\frac{x_{i j}-\min _{i} x_{i j}}{\max _{i} x_{i j}-\min _{i} x_{i j}} \quad X_{i} \in S \\
z_{i j}=\frac{\max _{i} x_{i j}-x_{i j}}{\max _{i} x_{i j}-\min _{i} x_{i j}} \quad X_{i} \in D
\end{gathered}
$$

Normalised formula changes the value of variable $X_{j}$ into $[0,1]$. Therefore, based on the set of variables normalised with this method it is possible to construct synthetic measure whose values are included in $[0,1]$. It is described by the following formula (3):

$$
Q_{i}=\frac{1}{k} \sum_{j=1}^{k} z_{i j}
$$

\section{REASERCH RESULTS}

The paper presents the proposal to apply the selected multidimensional methods of the comparative analysis for analysing the development level of rural areas of the Masovian voivodeship ${ }^{2}$. Information about municipalities was obtained from the Local Data Bank of the Central Statistical Office. Based on the literature [Zając 2006, Stanny 2015) the selection

\footnotetext{
${ }^{2}$ The paper undertakes to calculate the level of development of rural and urban-rural communes in the Mazowieckie province.
} 
of variables was carried out in terms of their relevance to demographic research, social infrastructure, selected aspects of the economic situation and technical infrastructure. It was also largely determined by the availability of data at the municipal level in the selected years. The study was conducted for data obtained from the Local Data Bank for 2004 and 2016.

The study presented in the paper was divided into two parts. In the first part of the analysis, the ranking of municipalities in 2004 and 2016 was created using the Q measure. In the second stage, three groups of municipalities were identified:

group 3. with the lowest degree of development

$$
m_{i}<\bar{m}-s_{M}
$$

group 2. with the medium degree of development

$$
\bar{m}-s_{M} \leq m_{i} \leq \bar{m}+s_{M}
$$

group 1. with the highest degree of development

$$
m_{i}>\bar{m}-s_{M}
$$

where $m_{i}$ - the value of the synthetic measure $Q_{i}$ ) for the $i$-th object (municipality), $\bar{m}$ and $s_{M}$ the mean and standard deviation of the synthetic measure.

The following information was used for the analyses:

- $\quad$ expenditure per capita in Section 801 - Education and upbringing

- $\quad$ expenditure per capita in Section 93 Culture and protection of the national heritage

- demographic load (people of the post-working age per 100 people at the working age),

- percentage of children aged 3-5 covered by the pre-school education,

- share of the registered unemployed in the working-age population,

- number of natural persons conducting a business activity per 1000 inhabitants (private sector),

- number of commercial companies per 1000 inhabitants (private sector),

- number of foundations, associations and social organizations per 10000 inhabitants,

- number of flats completed for use per 10000 inhabitants,

- using the installation in \% of the total population - water supply,

- $\quad$ using the installation in $\%$ of the total population - sewerage.

Table 1 presents the top 10 communes of the Masovian voivodeship in 2004 and 2016. Lesznowola is the leader every year. The next places are occupied by Kozienice and Wyszków (in 2004), and Michałowice and Nadarzyn (in 2016). The order of municipalities established on the basis of a synthetic measure built based on the zero unitarization method in 2004 (Tab. 1.) is not similar to that of 2016. The leader of the ranking - Lesznowola did not change its position. The next municipalities did not strongly change their positions in the ranking. The highest increase was recorded for the municipality of Dąbrówka, which moved by 201 positions, and the lowest for the municipalities of Raszyn and Kampinos. Some of municipalities (e.g. Błonie, Grodzisk Mazowiecki) did not change their position.

Table 1. Ranking of the best communes distinguished by the synthetic Q measure in 2004 and 2016

\begin{tabular}{|c|l|r|}
\hline \multicolumn{2}{|c|}{2004} \\
\hline $\begin{array}{c}\text { Position in the } \\
\text { ranking }\end{array}$ & Commune & Q measure \\
\hline 1 & Lesznowola & 0,49 \\
\hline 2 & Kozienice & 0,45 \\
\hline 3 & Wyszków & 0,45 \\
\hline 4 & Michałowice & 0,43 \\
\hline 5 & Wołomin & 0,42 \\
\hline 6 & Raszyn & 0,42 \\
\hline 7 & Piaseczno & 0,41 \\
\hline 8 & Błonie & 0,40 \\
\hline 9 & Łomianki & 0,39 \\
\hline 10 & Ożarów Mazowiecki & 0,38 \\
\hline
\end{tabular}

\begin{tabular}{|c|l|r|}
\hline \multicolumn{2}{|c|}{2016} & Q measure \\
\hline $\begin{array}{c}\text { Position in the } \\
\text { ranking }\end{array}$ & Commune & 0,68 \\
\hline 1 & Lesznowola & 0,55 \\
\hline 2 & Michałowice & 0,54 \\
\hline 3 & Nadarzyn & 0,49 \\
\hline 4 & Stare Babice & 0,48 \\
\hline 5 & Piaseczno & 0,48 \\
\hline 6 & Ożarów Mazowiecki & 0,47 \\
\hline 7 & Raszyn & 0,47 \\
\hline 8 & Błonie & 0,45 \\
\hline 9 & Izabelin & 0,43 \\
\hline 10 & Konstancin-Jeziorna & \\
\hline
\end{tabular}

Source: own study based on the Local Data Bank of the Central Statistical Office,

The spatial distribution of communes with low (group 3), medium (group 2) and high level (group 1) of development is presented in figure 1. One can notice the strong influence of Warsaw on the dynamic development of neighbouring mostly communes up to 10 counties. 
Majority of municipalities in the group with the highest degree of development are those constituting part of the Warsaw Metropolitan Area. In addition, the implementation of joint ventures of entities surrounding Warsaw with the capital will certainly contribute at least to maintain their development position against the other municipalities of the Masovia region, or even to a more dynamic development than it would have taken place in other municipalities of the voivodeship. It should also be noted that Warsaw Metropolitan Area, and therefore also the communes from the group with the highest level of development, is indicated as the largest centre of the economic growth not only in the Masovian voivodeship, but also in the whole country. This situation was underlined also by other authors (Dziemianowicz at all, 2014).

Remaining communes from the highest group (e.g. Kozienice, Wyszków, Iłża) are urban- rural communes. Only one of them (Iłża) was classified by Mazovian Statistical Office as a commune with the highest rural potential (Strzelecki (ed.) 2013).

Iłża is also one of the selected communes which were promoted to the highest group. Other communes (Garwolin, Żelechów, Jaktorów, Żabia Wola, Halinów, Wiązowna, Słupno, Radzymin, Radziejowice) which were promoted from the second group to the first one are mainly located in the neighbourhood of Warsaw or they have good communications with the capital.

Analysing the changes between 2004 and 2016, it could be underlined that selected communes (Łosice, Karczew, Przysucha, Pułtusk, Szydowiec, Leszno, Żuromin) moved from the highest group into the middle one. The majority of them are located on the peripheries of the voivodeship, so the influence of Warsaw is not significant.
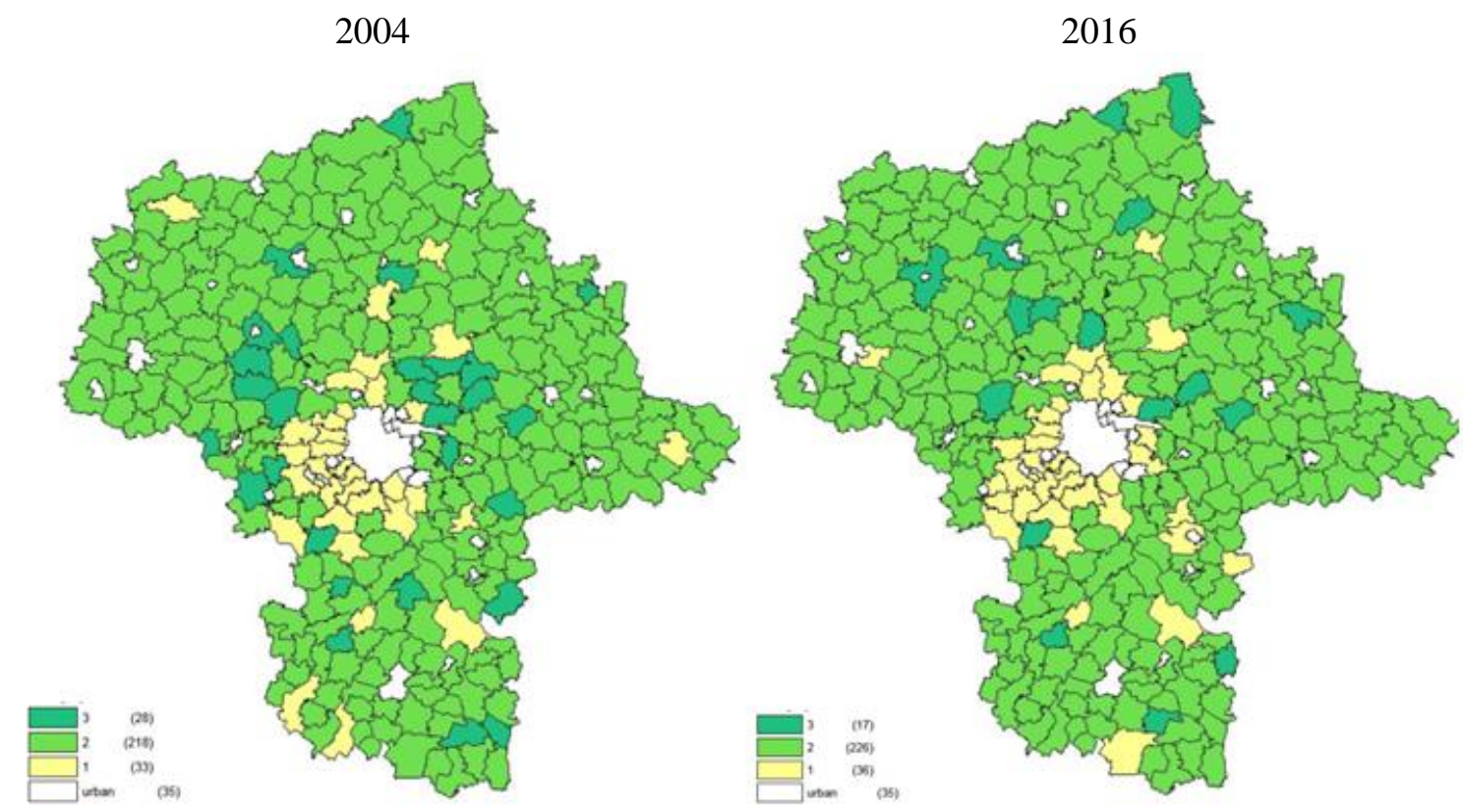

Figure 1. Division of municipalities created using the Q measure in 2004 and 2016

Source: own study based on the Local Data Bank of the Central Statistical Office, http://stat.gov.pl/bdl/app/strona.html?p_name=indeks (access 01.09.2017).

\section{CONCLUSIONS}

The Masovian voivodeship is characterised by a great diversity with respect to other regions of Poland and the European Union. The socio-demographic potential of this area is concentrated in the suburban area of Warsaw. The voivodeship is characterised by the lowest share of the registered unemployed in the country at the working age (6,2\% in 2017).

When analysing the rural areas of the Masovian voivodeship, one cannot talk about their homogeneity in terms of the examined features ${ }^{3}$. Three groups of communes distinguished during the studies, as well as their spatial analysis allowed the clear identification of the highest socio-economic development in the immediate vicinity of Warsaw and along the main transport routes in the capital. The weakest group, which consists mainly of the communes located far away from Warsaw (e.g. in the vicinity of the Eastern Poland voivodeships) or poorly connected with the capital, is particularly weak against this background.

When analysing the spatial changes that occur at the level of development of the municipalities in the Masovian voivodeship, one can notice a significant increase in the level of development in the analysed period for these communes, which are located in the vicinity of the newly built highways. On the basis of the conducted analyses, one can formulate a conclusion that we should seek funds for further improvement of infrastructure, especially in the communes located further from the capital.

\footnotetext{
${ }^{3}$ The condition of technical and social infrastructure, the number of functioning companies or the demographic structure
} 


\section{Proceedings of the $8^{\text {th }}$ International Scientific Conference Rural Development 2017}

It is very important to identify factors that may represent endogenous growth potential, as well as exogenous factors and the required external actions, supporting this development, to motivate the development of the weaker communities. Large distances from major urban centres, which seem to be a barrier to their development, with the appropriate transformation of the municipality's development profile (e.g. promoting the specialized commodity agriculture instead of tourism) can become a significant feature of these areas. Effective counteracting to threats and reversing the unfavourable trends require external support, including the use of the European Union instruments.

\section{REFERENCES}

1. Balicki, A. 2009. Statystyczna Analiza wielowymiarowa i jej zastosowania spoleczno-ekonomiczne. Wydawnictwo Uniwersytetu Gdańskiego, Gdańsk. [In Polish]

2. Bański, J., Czapiewski, K. Ł. 2008. Ekspertyza. Identyfikacja i ocena czynników sukcesu społeczno-gospodarczego na obszarach wiejskich. Instytut Geografii i Przestrzennego Zagospodarowania PAN, Warsaw . [In Polish]

3. Baran, A., Panek, T., Pustała, E. 1987. Powiazania procesów demograficznych i społeczno-ekonomicznych w wybranych krajach europejskich w latach 1950-1980. Seria Monografie i Opracowania, Warszawa. [In Polish]

4. Brodziński, Z. 2011. Stimulating rural development at the local level on the example of the communes of the Warmia and Masuria voivodeship. SGGW Publishing House, Warsaw

5. Chrzanowska, M., Drejerska, N. 2016. Evaluation of the socio-economic development level of communes in the Mazowieckie region with use of methods of the multivariate statistical analysis. Wiadomości Statystyczne, No. 6, pp. 59-69. [In Polish]

6. Dziemianowicz, W., Mackiewicz, M., Szmigiel-Rawska, K. 2014. Diagnoza obszaru metropolitalnego Warszawy. Raport syntetyczny. Geoprofit, Ecorys, Warszawa

7. Kukuła, K. 2012. Propozycja budowy rankingu obiektów z wykorzystaniem cech ilościowych oraz jakościowych. [w:] Binderman, Zieliński (red.): Metody ilościowe w badaniach ekonomicznych, Tom XIII/1, Warszawa. [In Polish]

8. Kukuła, K. 2014. Budowa rankingu województw ze względu na wyposażenie techniczne rolnictwa w Polsce. Wiadomości statystyczne, No. 7. [In Polish]

9. Mynarski, S. (ed.) 1999. Spatial research of the market and consumption. A methodical guide, Warsaw.

10. Pomianek, I., Chrzanowska, M., Bórawski, P. 2013. Zróżnicowanie poziomu rozwoju społeczno-gospodarczego obszarów wiejskich województwa warmińsko-mazurskiego na tle kraju według miernika Hellwiga. Zeszyty Naukowe OTN w Ostrołęce, No. XXVII, p. 442-456. [In Polish]

11. Stanny, M. 2015. Poziom rozwoju społeczno-gospodarczego obszarów wiejskich w Polsce -pomiar zjawiska złożonego. [In Polish]

12. Stanny, M. 2010. Spatial diversification of the balance on the labour market in rural areas in Poland. Bulletin of Geography SocioEconomic Series, No. 14, pp. 103-111.

13. Strzelecki Z. 2013. Social and economic situation and spatial development of the Mazovian region - conditions and trends. Mazowieckie Biuro Planowania Regionalnego w Warszawie, Warszawa

14. Sztompka, P. 2005. Socjologia zmian społecznych. Znak, Kraków

15. Wojewódzka-Wiewiórska, A., Dudek, H. 2016. Dynamics of rural areas development in Poland; convergence analysis. . Proceedings of 22nd Annual International Scientific Conference, Vol. 2, pp. 99-105, 18-20 May, Poland

16. Wysocki, F. 2010. Metody taksonomiczne w rozpoznawaniu typów ekonomicznych rolnictwa i obszarów wiejskich, Wydawnictwo Uniwersytetu Przyrodniczego w Poznaniu, Poznań.

17. Zajac, K., 2006. Czynniki demograficzne warunkujące rozwój społeczno-gospodarczy, Rektor's Lectures Nr 63, Akademia Ekonomiczna, Kraków. [In Polish]

18. Zielińska-Sitkiewicz, M. 2017. Classification of selected food industry companies listed on the Warsaw Stock Exchange - the impact of normalization procedures. Proceedings of the 2017 International Conference "Economic Science for Rural Development", No. 46, pp. 359-366, Jelgava

19. Ziemiańczyk, U. 2010. An assessment of socio-economic development of rural and urban-rural communities in the Małopolska province. Infrastruktura i Ekologia Terenów wiejskich, Vol. 14, pp.31-40. 